Pamiętnik Literacki CIII, 2012, z. 2

PL ISSN 0031-0514

Poznań, 16 kwietnia 2012

\title{
DO REDAKTOR NACZELNEJ
}

\author{
Prof. zw. dr hab. Grażyna Borkowska \\ Redaktor Naczelna „Pamiętnika Literackiego” \\ Pl. Nankiera 15 \\ 50-140 Wrocław
}

Nawiązując do korespondencji uprzednio drukowanej na łamach „Pamiętnika Literackiego" (w zeszytach: 2/2009; 4/2009; 2/2010) dotyczącej zarzutu popełnienia plagiatu przez dr. hab. Janusza K. Golińskiego, który znaczną część rozdziału 1 mojej rozprawy doktorskiej opublikował pod swoim nazwiskiem w wydanym w 2008 roku w Warszawie tomie zbiorowym „Wszystko tu najdzie, co wy macie w głowie”. Świat prozy staropolskiej (red. E. Lasocińska i A. Czechowicz; tytuł artykułu: ,Szczęście monarchijej ” $i$,, umiłowanie mądrości”. O idei króla i filozofa oraz jej przywołaniach w renesansowej prozie polskiej), uprzejmie informuję, że sprawa została formalnie zakończona.

Rzecznik Dyscyplinarny oskarżył dr. hab. Janusza Golińskiego, profesora UMK, o przywłaszczenie sobie autorstwa cudzego utworu, tj. o czyn uchybiający obowiązkom nauczyciela akademickiego i godności nauczyciela akademickiego, określony w art. 139 ust. 1 w zw. z art. 144 ust. 3 pkt 1 ustawy z dnia 7 lipca 2005. Prawo o szkolnictwie wyższym. Zarzuty zostały formalnie potwierdzone i udowodnione, i na tej podstawie 11 stycznia 2011 Komisja Dyscyplinarna dla Nauczycieli Akademickich Uniwersytetu Mikołaja Kopernika w Toruniu wydała „Orzeczenie”, w którym uznano „obwinionego dr. hab. Janusza Golińskiego za winnego zarzuconego mu czynu” i wymierzono wymienionemu „karę pozbawienia prawa wykonywania zawodu nauczyciela akademickiego na okres 8 lat". Orzeczenie jest prawomocne.

Zakończyło się również postępowanie karne w wymienionej sprawie, prowadzone przez Sąd Rejonowy w Toruniu, II Wydział Karny, z aktu oskarżenia wniesionego przez tamtejszą Prokuraturę Rejonową. Podczas rozprawy oskarżony przyznał się do popełnienia plagiatu, stąd 16 czerwca 2011 sędzia Sądu Rejonowego Ewa Lemanowicz-Pawlak orzekła, że „oskarżonego Janusza Golińskiego uznaje za winnego popełnienia zarzuconego mu czynu stanowiącego występek z art. 115 ust. 1 Ustawy z dnia 4 lutego 1994 r. o prawie autorskim i prawach pokrewnych", i wymierzyła mu karę grzywny 5000 zł oraz wypłatę zadośćuczynienia w wysokości 30000 zł na rzecz „oskarżycielki posiłkowej Agnieszki Raubo". Wyrok jest prawomocny i kwota zadośćuczynienia została uiszczona.

Mam nadzieję, iż niniejsze przedstawienie faktów pozwoli ostatecznie zamknąć bolesną dla mnie sprawę, która poruszona została kilkakrotnie w „Pamiętniku Literackim”. Wierzę, iż ten list stanowić będzie ważną informację dla czytelników i badaczy literatury staropolskiej, którzy zapewne nie chcieliby cytować lub odnotowywać w swych publikacjach artykułu, który został ogłoszony z naruszeniem moich praw autorskich. 
Na potwierdzenie prawdziwości przedstawionych faktów mogę udostępnić kopię „Orzeczenia Dyscyplinarnego” wraz z pismem Rektora UMK, prof. Andrzeja Radzimińskiego, jak również kopię wyroku sądowego.

$\mathrm{Z}$ wyrazami szacunku

dr Agnieszka Raubo

(adiunkt w Zakładzie Literatury Staropolskiej i Oświecenia, Wydział Filologii Polskiej i Klasycznej UAM w Poznaniu) 